\title{
The Circadian Timing System: Making Sense of day/night gene expression
}

\author{
HANS G. RICHTER ${ }^{1}$, CLAUDIA TORRES-FARFÁN ${ }^{2}$, PEDRO P. ROJAS-GARCÍA ${ }^{2}$, \\ CARMEN CAMPINO ${ }^{3}$, FERNANDO TORREALBA ${ }^{2}$ and MARÍA SERÓN-FERRÉ ${ }^{2}$
}

\footnotetext{
${ }^{1}$ Instituto de Histología y Patología, Facultad de Medicina, Universidad Austral de Chile, Valdivia, Chile

${ }^{2}$ Unidad de Reproducción y Desarrollo, Departamento de Ciencias Fisiológicas, Facultad de Ciencias Biológicas and ${ }^{3}$ Departamento de Endocrinología, Facultad de Medicina, Pontificia Universidad Católica de Chile, Santiago, Chile
}

\begin{abstract}
The circadian time-keeping system ensures predictive adaptation of individuals to the reproducible 24-h day/ night alternations of our planet by generating the 24-h (circadian) rhythms found in hormone release and cardiovascular, biophysical and behavioral functions, and others. In mammals, the master clock resides in the suprachiasmatic nucleus ( $\mathrm{SCN}$ ) of the hypothalamus. The molecular events determining the functional oscillation of the SCN neurons with a period of 24-h involve recurrent expression of several clock proteins that interact in complex transcription/translation feedback loops. In mammals, a glutamatergic monosynaptic pathway originating from the retina regulates the clock gene expression pattern in the SCN neurons, synchronizing them to the light:dark cycle. The emerging concept is that neural/humoral output signals from the SCN impinge upon peripheral clocks located in other areas of the brain, heart, lung, gastrointestinal tract, liver, kidney, fibroblasts, and most of the cell phenotypes, resulting in overt circadian rhythms in integrated physiological functions. Here we review the impact of day/night alternation on integrated physiology; the molecular mechanisms and input/output signaling pathways involved in SCN circadian function; the current concept of peripheral clocks; and the potential role of melatonin as a circadian neuroendocrine transducer.
\end{abstract}

Keyterms: biological rhythms, circadian timing system, clock genes, melatonin

Earth rotation imposes 24-hour rhythms to integrated physiological functions

A key evolutionary feature common to all organisms is predictive adaptation to the day/night alternation derived from the Earth's rotation every 24-h (Moore-Ede et al., 1982; Edery, 2000). The 20 ${ }^{\text {th }}$ century saw the recognition that all living beings, including unicellular organisms, posses a biological clock system that measures time in near 24-h (circadian) units resulting in rhythmic patterns with a period of $24-\mathrm{h}$, termed circadian rhythms. The tendency of some organisms to sleep at night and some during the day, and the fact that some plants open their leaves during the day and close them at night, are common observations. The reasonable assumption that these are passive responses to the day/night changes in the environment was proven wrong by a simple yet brilliant experiment performed in the $18^{\text {th }}$ century. In 1729, French astronomer Jean Jacques d'Ortous de Mairan showed that the upright movement of the leaves of the plant Mimosa pudica at nighttime and the opening of these leaves during the daytime hours continued over several days when the plant was maintained in constant darkness, indicating that the leaves' movement followed an endogenous 24-h clock (MooreEde et al., 1982).

Almost every physiological variable in living organisms shows a circadian rhythm 
(for activity/rest, body temperature, and plasma melatonin concentration circadian rhythms in laboratory animals, see Fig. 1). Even complex physiological processes such as childbirth show circadian rhythms; in most women labor begins after midnight and delivery occurs around early morning (Glattre and Bjerkedal, 1983). In individuals exposed to the light:dark (LD) cycle, the phase (i.e. clock time of the peak or through) of a given rhythm will be similar for different individuals. In the absence of LD signals (by exposure to constant light or darkness, as well as in the blind), rhythms persist in individuals but with a period close to, but not exactly, 24-h (Enright, 1981). The circadian time-keeping system is actively engaged in the maintenance of normal physiology, not only in adults, but also during development, given that 24-h rhythms in hormones, behavior, and cardiovascular function are present in human, monkey, and sheep fetuses (Serón-Ferré et al., 1993).

The peak and trough of the rhythms for different physiological variables occur at

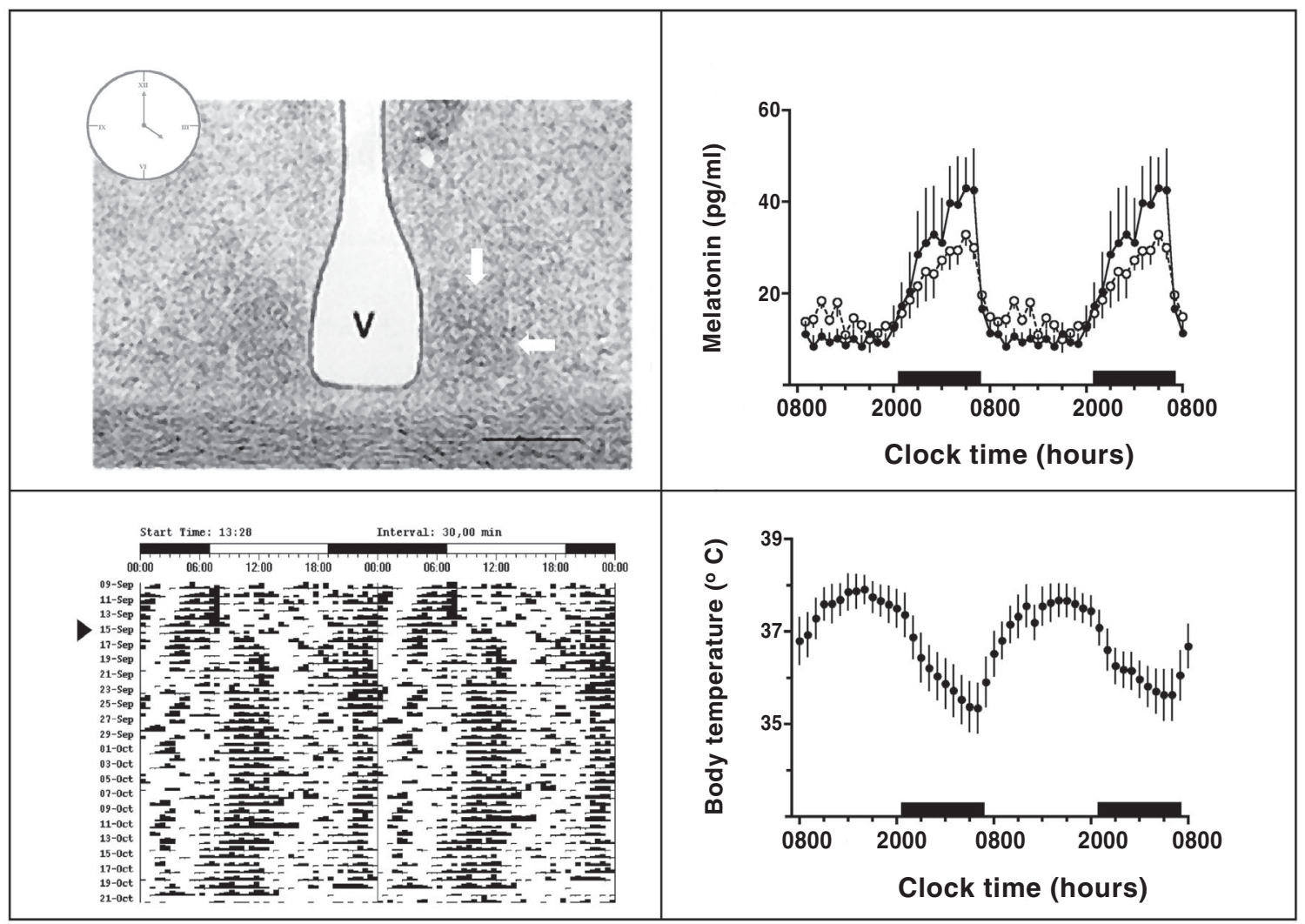

Figure 1. Photomicrograph of the master circadian clock, the suprachiasmatic nucleus (SCN), and examples of overt circadian rhythms in several mammalian species. Upper left panel: coronal section of Nissl stained fetal sheep bilateral suprachiasmatic nuclei (SCN; one is indicated by white arrows); V: third ventricle, bar: $500 \mu \mathrm{m}$. Upper right panel: melatonin rhythm in pregnant ewes and their fetuses (closed and open circles, respectively); (mean \pm S.E.; $n=4)$. Lower left panel: double plot of locomotor activity rhythm in a rat. Each line represents the recordings of two successive days. Initial recordings were done under ad libitum feeding in which the rat shows a nocturnal pattern of activity. The arrow indicates initiation of a restricted pattern of feeding in which food was available from 10:00 to 11:00 hours. Note the shift in the activity rhythm. Lower right panel: body temperature rhythm in adult capuchin monkeys (mean \pm S.E.; $n=4$ ). Dark bars indicate hours without light. 
different clock times within an individual, for instance, in humans under normal LD conditions, cortisol peaks at 0800-h, while temperature peaks at $1400-\mathrm{h}$ and melatonin at $0200-\mathrm{h}$. In nocturnal animals, such as the rat, corticosterone peaks in the evening and temperature at night, whereas melatonin shows the same phase as in humans and other diurnal animals. The phase relationship between the circadian rhythms of different physiological variables in the 24-h cycle is known as internal temporal order (Moore-Ede et al., 1982; Edery, 2000), the importance of which becomes clear under normal and pathological conditions in the adult human. In normal subjects, the transient abnormalities derived from intercontinental flights (jet lag) and the adverse effects on working capability after alternate diurnal and nocturnal working schedules are ascribed to an alteration of the internal temporal order (Gold et al., 1992). In clinical practice, it is important to consider circadian rhythms in pharmacokinetics and cell responses to therapy in order to design proper protocols for drug administration (Belanger et al., 1997; Levi, 1997).

In mammals, circadian rhythms are governed by a master clock located in the hypothalamus, which is entrained to environmental signals and commands peripheral oscillators. The use of molecular biology-based approaches, particularly mutational studies, has allowed the identification of a set of genes directly involved in the generation of circadian rhythms, which have been named clock genes. What follows is a review of the components of the circadian time-keeping system, with particular emphasis on molecular mechanisms and the potential role of melatonin as a circadian neuroendocrine transducer.

The mammalian master clock resides in the suprachiasmatic nucleus

The circadian timing system is a supraphysiological system that comprises a hierarchy of biological clocks (peripheral oscillators; see below) commanded by a central nervous system clock (pacemaker).
Such an organization was an early proposal, given that in the 1960s, the existence of circadian rhythms in some physiological variables was demonstrated in dispersed liver cells and in heart, gut, and adrenal explants culture. These and other findings led to a proposal that in mammals and other organisms, the circadian timing system would involve a hierarchy of biological clocks (Moore-Ede et al., 1982).

Systematic lesions of several areas of the hypothalamus in a variety of species that resulted in loss of circadian rhythms, including the locomotor activity rhythm, allowed the identification of the suprachiasmatic nucleus ( $\mathrm{SCN}$ ) of the anterior hypothalamus as a possible site of the biological clock in mammals (Moore and Eichler, 1972; Stephan and Zucker, 1972). A key experiment was the demonstration that activity rhythms were restored by re-grafting the SCN from normal animals (DeCoursey and Buggy, 1989). The definitive finding was the identification of a mutant hamster (tau) displaying a shortened 20-h locomotor activity period that allowed crossed grafting between mutant and normal hamsters with a 24-h locomotor activity period. Thus, lesion of the SCN of a normal animal followed by SCN grafting from a mutant animal restored the locomotor activity rhythm in the recipient animal, but displaying the 20-h period from the donor. This elegant experiment demonstrates that the SCN commands the circadian rhythm of locomotor activity (Ralph and Menaker, 1988; Ralph et al., 1990).

In humans, two clinical correlates showing the importance of the $\mathrm{SCN}$ function have been reported. The destruction of the SCN by a tumor resulted in the disappearance of the circadian rhythm of temperature (Schwartz et al., 1986). In another patient, an SCN lesion due to the surgical removal of a hypothalamic tumor resulted in an altered pattern of sleep/wake and body temperature rhythms in the 24-h period. Interestingly, although this patient maintained her intellectual capacities, she showed an impairment of reproducibility in performing the same intellectual tasks when tested on successive days (Cohen and Albers, 1991). 
In the rat, each of the bilateral SCNs is formed by a network of approximately 10,000 neurons located on both sides of the third ventricle over the optic chiasm (Moore et al., 2002, and references therein; see Fig. 1, upper left panel, for a coronal section of the fetal sheep SCN). These neurons already exhibit oscillatory activity during fetal life. In rat, non-human primates, and sheep fetuses, the SCN neurons display a day/night rhythm of metabolic activity and $c$-fos expression, which, as in the adult SCN, is higher at noon than at midnight, indicating entrainment of the SCN neurons to the LD cycle (Serón-Ferré et al., 1993). The intrinsic oscillatory capacity of the SCN neurons in vivo has been demonstrated by recording electrical activity over 24-h using chronically-implanted electrodes (Kubota et al., 1981; Yamazaki et al, 1998) and also by measuring metabolic activity at discontinuous points in time as 2deoxyglucose uptake (Schwartz, 1991) and $c$-fos expression (Earnest et al., 1990). The electrical and metabolic oscillatory capacity is maintained for long periods of culture, either as hypothalamic slices (Gillette and Prosser, 1988) or dispersed SCN neurons (Welsh et al, 1995). The latter evidence indicates that the isolated neurons of the $\mathrm{SCN}$ are single-cell circadian oscillators.

\section{Suprachiasmatic nucleus entrainment pathways}

Light synchronizes the SCN to the 24-h LD cycle, inducing phase shifts in SCN neuronal activity. In several mammals, a bright light pulse applied at early night will delay the phase of the locomotor activity circadian rhythm, whereas at late night it will advance the phase. LD information reaches the SCN neurons through the retinohypothalamic tract. This monosynaptic tract originates primarily from a subset of retinal ganglion cells that express the photopigment melanopsin (Gooley et al., 2003). The retinohypothalamic pathway is anatomically and functionally different from the neural pathway used for pattern vision and uses glutamate and PACAP (pituitary adenylate cyclase-activating polypeptide) to convey light information (Hannibal, 2002; Gooley et al, 2003). Until recently, light entrainment was thought to rely upon photopigments different from those classically present in rods and cones, such as melanopsin (an opsin-based photopigment expressed in a subset of retinal ganglion cells), because mice lacking rods and cones could be entrained by light (Freedman et al., 1999) and melanopsin-containing retinal ganglion cells are light-sensitive (Berson et al., 2002; Hattar et al., 2002). This hypothesis was tested by analyzing locomotor activity under different lighting conditions in mice with a targeted disruption of the melanopsin gene (Ruby et al., 2002; Panda et al., 2002a). In these mice, light still resets the circadian clock, but the magnitude of phase shifts of the activity rhythms induced by light is decreased. Both reports concluded that melanopsin contributes to, but it is not essential for, resetting the locomotor rhythm at low and medium light levels. Melanopsin may then act in concert with classical photopigments present in rods and cones, which send light information to melanopsincontaining retinal ganglion cells (Ruby et al., 2002; Panda et al., 2002a). Entrainment or synchronization to the day/night cycle requires glutamate and PACAP binding to receptors expressed by the SCN neurons, which evoke second messengers activation that in turn induce expression of the clock gene Perl (Hannibal, 2002; see below).

The adult pattern of SCN innervation by the retinohypothalamic tract is attained during late gestation in the human, nonhuman primates, and sheep (Torrealba et al., 1993; Hao and Rivkees, 1999), whereas it is attained post-natally in the rat and hamster (Müller and Torrealba, 1998). Since only a limited amount of environmental light reaches the fetus, light cannot be an entrainment signal for the fetus (Parraguez et al., 1998). Current evidence suggests that the fetal $\mathrm{SCN}$ is entrained by a maternal signal, a possibility that is supported by the identification of melatonin binding sites in the fetal SCN from human and rat (Reppert et al., 1988; Naitoh et al., 1998) and D1 dopamine receptors in the $\mathrm{SCN}$ of rat fetuses (Naitoh et al., 1998) and newborn 
baboons (Rivkees and Lachowicz, 1997). In fact, it has been shown that periodic administration of melatonin or D1dopaminergic agonist SKF38393 to pregnant hamsters with SCN lesions are capable of entraining the biological clock in the fetal SCN (Davis and Mannion, 1988; Viswanathan et al., 1994).

\section{Suprachiasmatic nucleus output pathways}

The basis of the SCN communication with effectors responsible for the overt physiological rhythms are not well understood. An important question is how the SCN differentially commands a wide range of physiological and behavioral rhythms, such as activity/rest, sleep/wake, body temperature, heart rate, liver and kidney function, up to endocrine rhythms such as those of melatonin, cortisol, gonadotropins and prolactin, among many others. Different peptidergic neuronal subtypes are present in the SCN, which synthesize and release vasopressin (AVP), vasoactive intestinal peptide (VIP), somatostatin, and gastrin-releasing peptide (GRP), etc. Two neurotransmitters are present in a high percentage of synaptic terminals emitted by the $\mathrm{SCN}$ neurons, namely GABA (gamma-aminobutyric acid) and glutamate. Inside the medial hypothalamus, the SCN efferent fibers innervate the medial preoptic area, the subparaventricular nucleus, the dorsomedial nucleus and the paraventricular nucleus (PVN). The neurons innervated by the SCN in these regions belong to one of the following types: endocrine neurons such as GnRH-, TRH- and CRH-containing neurons, autonomic neurons or intermediate neurons. The SCN also projects to extra hypothalamic structures such as the paraventricular nucleus of the thalamus and the intergeniculate leaflet (Kalsbeek and Buijs, 2002). Experiments using retrograde viral tracers have identified multi-synaptic networks connecting the SCN with several organs. The best known of these pathways is the SCN-pineal gland connection, involved in the generation of melatonin rhythm through the innervation network: SCN-PVN-preganglionar neurons from the intermediolateral columns of the spinal chord-sympathetic neurons from the superior cervical ganglion-pineal organ (Fig. 2; Ganguly et al., 2002). An analogous innervation pathway connecting the SCN with the adrenal cortex has been described (Buijs et al., 1999).

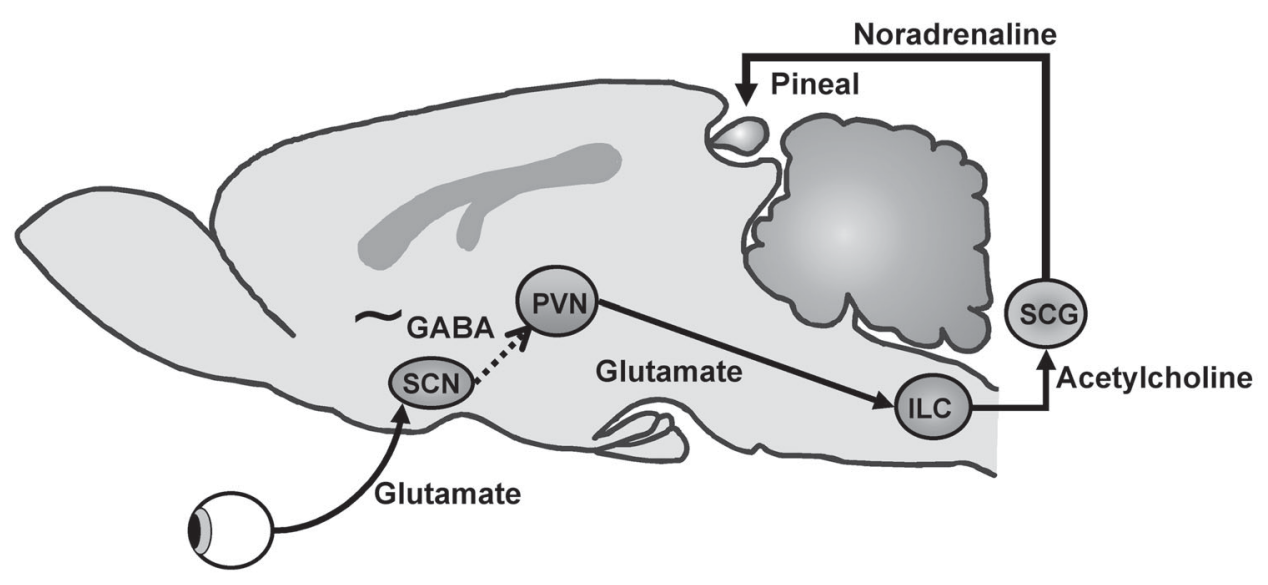

Figure 2. Schematic representation of the multisynaptic pathway underlying photic and circadian control of melatonin synthesis in the pineal gland. Glutamate released from the retinohypothalamic tract stimulates the suprachiasmatic nucleus (SCN) GABAergic neurons, which in turn inhibit the stimulatory action of the paraventricular nucleus (PVN) on melatonin secretion by the pineal organ. ILC: intermediolateral columns from the spinal chord; SCG: superior cervical ganglion. The symbol $\sim$ indicates circadian GABA ( $\gamma$-aminobutyric acid) releasing. 
It has been proposed that the connections between the SCN and the autonomous nervous system underlie the signaling of circadian information to the pancreas, liver, heart and even to muscle (Kalsbeek and Buijs, 2002; Terazono et al., 2003) and adipose tissue (Kalsbeek et al., 2001). The importance of the neural pathway between the SCN and the peripheral tissues for the regulation of circadian rhythms has been demonstrated in animals in which lesion of the SCN is followed by SCN grafting. The grafted SCN exhibits a very limited capacity to reinnervate other hypothalamic zones (Silver et al., 1996). Of note, the grafted animals recover the activity/rest rhythm but not endocrine rhythms such as those of adrenal function, plasma melatonin and the gonadotropins cyclic secretory pattern (Meyer-Bernstein et al., 1999), unless neural connections between the graft and the hypothalamus of the host are present (de la Iglesia et al., 2003). These experiments show that the SCN regulates rhythms such as activity by secreting diffusible factors. Recently, prokineticin 2-containing neurons have been described in the SCN, which are apparently involved in the regulation of locomotor activity rhythm (Cheng et al., 2002). In contrast, the SCN control over endocrine rhythms seems to require intact efferent axonal projections from the $\mathrm{SCN}$.

The molecular machinery underlying circadian oscillation involves coordinated expression of clock genes

The analyses of different experimental models (cyanobacteria, Neurospora, Drosophila and mice) established the molecular interactions that underline the basic self-sustaining oscillatory process in biological clocks. In these species, mutational studies characterized a set of genes that result in the disruption of the normal circadian rhythm of locomotor activity when altered. These genes -called clock genes- are highly conserved between Drosophila and mouse. In the latter, the core clock genes are Per (period; with 2 homologues, Perl and Per2), Clock (circadian locomotor output cycles kaput), Bmall (brain and muscle aryl hydrocarbon receptor nuclear translocator [ARNT]-like protein 1), and Cry (cryptochrome; with 2 homologues, Cryl and Cry2) (Edery, 2000; Reppert and Weaver, 2002; Okamura et al., 2002). A third Per homologue, Per3, although expressed in the mouse $\mathrm{SCN}$, may not play a role as a core clock gene as its disruption produces only subtle alterations of the locomotor activity rhythm (Shearman et al., 2000a). In the rodent SCN and peripheral oscillators, the 24-h expression pattern of the Bmall gene is characterized by robust oscillatory levels of Bmall transcripts in antiphase with those of Per and Cry; whereas the level of Clock transcripts remains stable in the 24-h (Reppert and Weaver, 2002; Okamura et al., 2002; Balsalobre, 2002). However this may not be a general rule, because in sheep a robust oscillation of Clock mRNA in the SCN was found by in situ hybridization (Lincoln et al., 2002). Whether this situation will apply to other diurnal mammals remains to be established. Yu et al. (2002) characterized the genomic structure of the mouse Bmall gene and defined its promoter region. These authors demonstrated that Bmall transcription is activated by CRY1, CRY2, and PER2 proteins, but repressed by CLOCK/BMAL1 heterodimers.

At the protein level, circadian oscillation of clockwork negative factors is well established, as PER1, PER2 and CRY1 accumulate in the nuclei of SCN neurons at the end of subjective day and disappear at the end of circadian night (Maywood et al., 2003, and references therein). There is conflicting evidence on the circadian expression of BMAL1 protein, the dimerization partner of CLOCK (see below). Tamaru et al. (2000), produced polyclonal antibodies against amino acids 154-182 of the rat splice variant BMAL1b and analyzed the SCN of this species by immunoblot. The authors reported circadian oscillation of the BMAL1b protein content with peak at midnight (CT18) and trough at midday (CT06), and a rapid reduction of BMAL1b after exposure to light at early night. Maywood et al. (2003) showed circadian oscillation of the BMAL1 protein in the mouse SCN by immunocytochemistry, immunoblot, and co-immunoprecipitation 
studies using commercial antibodies. However, these authors found a BMAL1 content with peak during daytime (CT0-8) and trough during nighttime (CT12-20). In a third report, polyclonal antibodies raised against amino acids 381-579 of the mouse BMAL1 protein (Lee et al., 2001) were used for immunocytochemical and immunoblot analyses (von Gall et al., 2003); but these authors did not detect BMAL1 oscillation and showed that a light pulse at early night does not modify SCN BMAL1 protein content. Hence, further analyses are needed to decipher the actual circadian expression pattern of the BMAL1 protein in the $\mathrm{SCN}$ of rodents. In these animals, CLOCK protein shows stable levels in the 24-h cycle; in fact, CLOCK is a nuclear antigen constitutively expressed in the mouse SCN (Maywood et al, 2003; von Gall et al., 2003).

A model of the basic oscillatory process consisting of one transcription/translation negative feedback loop was introduced by Rensing (1997). In the following years, the use of genetic, molecular and biochemical approaches to studying the circadian timing system of mice provided convergent evidence defining a model based on two limbs of interacting positive and negative transcription/translation feedback loops that drive recurrent rhythms in the mRNA and protein levels of key clock components (Dunlap, 1999; Edery, 2000; Hastings 2000; Reppert and Weaver, 2002; Okamura et al., 2002). The constitutively expressed CLOCK has the potential to make temporally specific associations, alternating between BMAL1 and PER/CRY, thus resulting in transcriptional activation or repression, respectively (Maywood et al., 2003). However, according to Lee et al. (2001), circadian rhythmicity is mainly due to coordinated oscillation and timed posttranslational modifications of the negative regulators PER and CRY, which interact with the heterodimer CLOCK/ BMAL1 that would remain constitutively bound to the E-box motifs present in the promoter region of clock genes (as shown by chromatin immunoprecipitation assays), thus repressing its positive drive (see below; Lee et al., 2001; Reppert and Weaver, 2002).
The core stimulatory loop, driven by the heterodimer CLOCK/BMAL, upregulates the transcription of the clock genes Perl-3 and Cryl-2, which contain the enhancer sequences known as E-box (canonical core sequence: CACGTG) in their promoter regions (Reppert and Weaver, 2002; Okamura et al., 2002). This positive (feedforward) transcription/translation loop is recurrently counterbalanced by the core inhibitory loop formed by the proteins encoded by Perl-2 and Cryl-2 genes. Those PER proteins that escape hyperphosphorylation and degradation, homodimerize in the cytoplasm and, upon translocation to the nucleus, heterodimerize with the other negative elements, CRY1 and CRY2. The PERs/CRYs heterodimers interact with the CLOCK/BMAL1 complex, inhibiting its transcriptional induction on the Per genes, thereby closing the negative transcription/translation feedback loop (Reppert and Weaver, 2002; Okamura et al., 2002). In addition, the PER 2 protein has a positive effect on Bmall mRNA levels (Shearman et al., 2000b; Yu et al., 2002). Timed accumulation of PER/CRY complexes is regulated by casein kinase I $\varepsilon$ and $\delta$, which phosphorylate clock proteins and tag them for degradation (Lee et al., 2001). The importance of this process is highlighted by the shorter circadian period displayed by casein kinase $l \varepsilon$ mutant hamsters (tau), as a result of decreased turnover of the negative clock element PER (Lowrey et al., 2000; Reppert and Weaver, 2002; Okamura et al., 2002). As a whole, this clockwork mechanism helps to explain daily robust waves of E-box-containing genes expression. When levels of PER and CRY proteins are high, they interact to repress their own transcription. This results in derepression of CLOCK and BMAL1, therefore allowing a new cycle of E-boxbased gene expression to begin (Fig. 3).

The expression of the Perl gene is regulated by other transcription factors in addition to the CLOCK/BMAL1 complex. In the mouse, the promoter region of the three Per genes contain E-boxes, but only Perl and Per2 contain CREs (cAMP response elements; Travnickova-Bendova et al., 2002). These authors provided evidence accounting 


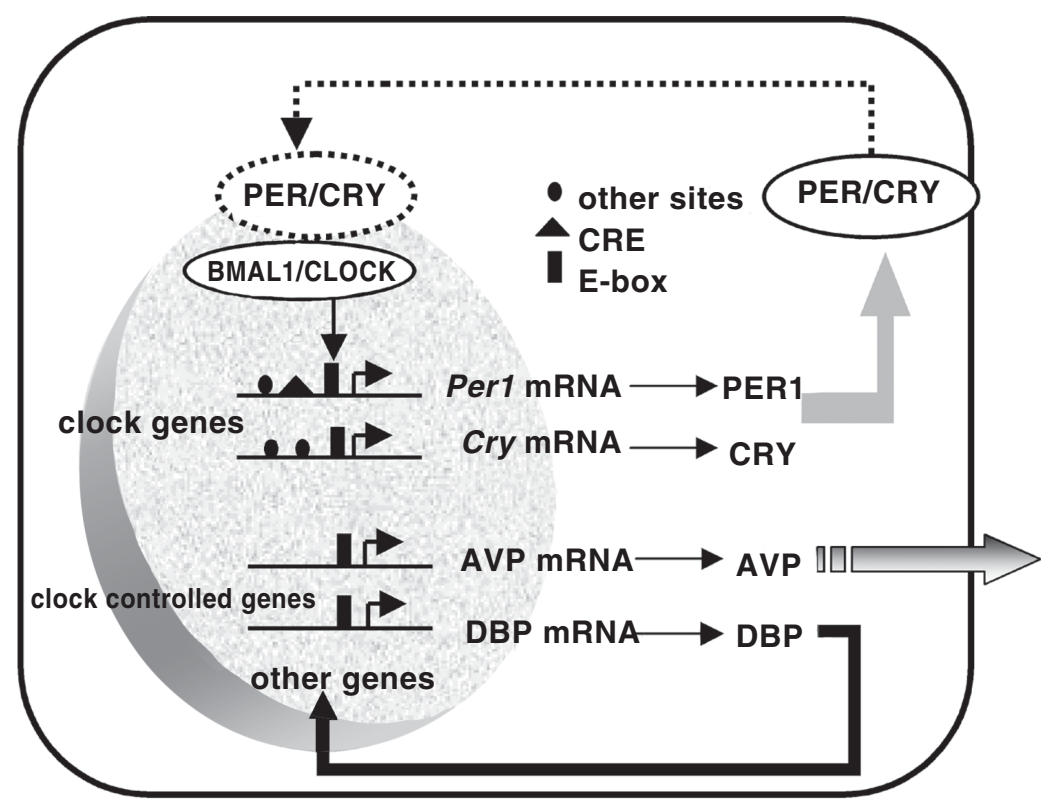

Figure 3. Simplified diagram showing the basic molecular loops that control clock gene expression in a neuron of the suprachiasmatic nucleus. The BMAL1/CLOCK heterodimer binds to E-box DNA motifs at the promoter region of the Per and Cry genes, activating its transcription (stimulatory loop). The core inhibitory loop, indicated by broken lines, is formed by the PER and CRY proteins. These proteins heterodimerize and the PERs/CRYs heterodimers interact with the CLOCK/BMAL1 complex, inhibiting its transcriptional induction on the Per and Cry genes. The CLOCK/BMAL1 heterodimer also induces the transcription of other genes containing E-box elements in their promoters, such as vasopressin (AVP; a neuropeptide secreted by the SCN) and albumin gene D-site binding protein (DBP; a transcription factor expressed in central and peripheral tissues). DBP will in turn rhythmically activate the transcription of other genes containing D-site motifs in their promoter regions. See text for further details.

for $\mathrm{Ca}^{2+}$-mediated phosphorylation of $\mathrm{CREB}$ (cAMP response element-binding protein) on residues serine 133 and 142 (Ginty et al, 1993 and Gau et al., 2002; respectively), which in turn binds to CREs in the promoters of Perl and Per2. Interestingly, the responsiveness of the Perl promoter region to $\mathrm{CREB}$ is remarkably higher than that of Per2, suggesting that the apparently functional Per2 CRE is actually inactivated by the entire promoter context (Travnickova-Bendova et al., 2002). Given that in the SCN, a light pulse triggers phosphorylation of the transcription factor CREB, which in turn quickly induces Perl gene transcription, while the Per2 gene responds more slowly, these authors concluded that the different activation potential of Perl and Per 2 CREs could account for the diverse induction kinetics of these two genes. Overall, current evidence suggests that functional cAMP response elements on the promoter region of the Perl gene are the targets to trigger lightinduced phase shifting of clock gene expression in the SCN of mammals.

In addition to the E-box and CRE sites, other response elements have been identified in the promoter region of the Per genes. The search for additional transcription factors regulating clock gene expression has yielded two PAR (proline and acid amino acid rich) family transcription factors and two basic helixloop-helix transcription factors. One PAR factor is DBP (named for albumin gene Dsite binding protein), which is rhythmically 
expressed in several tissues and exhibits high daytime levels (Okamura et al., 2002). DBP knockout mice show disruption of the circadian component of sleep, which is the cyclic tendency to sleep at night in diurnal animals, suggesting that DBP may feedback to the clockwork mechanism (LopezMolina et al., 1997). DBP binds to the specific sequence ATTACGTAAC (D-site) located upstream of the second transcription initiation site (1B site) of Perl and further increases its transcription rate driven by the CLOCK/BMAL1 complex (Okamura et al, 2002). Another PAR family transcription factor is E4BP4 (named for adenovirus E4 promoter ATF side-binding protein), found by Doi et al. (2001) in the chick pineal gland (an autonomous oscillator in birds). The phase of E4BP4 expression was nearly opposite that of PER2, and these authors identified potential binding sites for E4BP4 in the promoter of Per2. When a luciferase construct containing the 5'-flanking region of the Per2 gene was cotransfected with an E4BP4 expression construct, Per 2 promoter activity was repressed (Doi et al., 2001). Finally, the basic helix-loop-helix transcription factors Dec1 and Dec2 are rhythmically expressed in the mouse SCN with a peak in the subjective day. They are able to repress CLOCK/BMAL1-induced transactivation of the mouse Perl promoter (Honma et al., 2002), and therefore may contribute to the downregulation of Perl. Evidence indicating that the mRNA levels of Cry1, but not of Per2, were prematurely elevated in the livers of Rev-Erbo-deficient mice, led Etchegaray et al (2003) to investigate whether Rev-Erb $\alpha$ affected Cryl transcription. Using a combination of computer-based analyses, electrophoretic mobility shift assays, and luciferase reporter gene assays, these authors showed that Rev-Erbo acts as a transcriptional repressor of Cryl.

Additional mechanisms other than transcription factor binding contribute to the regulation of clock gene expression. Chromatin remodeling complexes might temporally regulate rhythmic gene expression exhibited by clock genes in the circadian feedback loop (Crosio et al., 2000), and histone acetylation is important in the regulation of clock gene expression in the liver (Etchegaray et al., 2003) and heart (Curtis et al., 2003). The metabolic state of the cell seems to be very important in regulating the expression of clock genes. The McKnight group (Rutter et al., 2001) found that in a purified system, the reduced forms of nicotinamide adenine dinucleotide (NADH/NADPH) cofactors strongly enhance DNA binding of the CLOCK/ BMAL1 heterodimer to its recognition sequence, whereas the oxidized forms are inhibitory. This means that the redox state of the cell may be crucial to induce or repress clock gene expression.

All clock gene homologues have been identified in the human genome, and the first mutation of a clock gene has recently been characterized in humans. A mutated phosphorylation site in the hPER 2 protein gives rise to a sleep pattern disorder known as familial advanced sleep phase syndrome (Toh et al., 2001); this finding is in agreement with that of a mutant hamster (tau) displaying a shorter locomotor activity period due to a mutation of the gene encoding for casein kinase Ie that results in reduced phosphorylation of the negative clock element PER2 (see above). On the other hand, polymorphisms of hClock (Katzenberg et al., 1998) and hPer3 (Archer et al., 2003) are associated with morning/evening preferences, i.e. the propensity of some organisms to behave as larks or owls, respectively; whereas polymorphism of hPerl is not associated with diurnal preference in normal adults (Katzenberg et al., 1999).

Hundreds of genes are under circadian control in the suprachiasmatic nucleus and peripheral tissues

As discussed, the neurons of the SCN are known to coordinately express clock genes. However, the link between oscillatory expression of clock genes and circadian SCN function as electrical and metabolic rhythmic activity over 24-h, remains largely unknown. By using microarray technology, hundreds of genes displaying a circadian pattern of expression have recently been identified in SCN and liver, in addition to the oscillatory canonical clock genes 
(Panda et al., 2002b). These authors estimate that up to $10 \%$ of the mammalian transcriptome may be under circadian control. The oscillatory genes found by Panda et al. (2002b) and other authors (see Ueda et al., 2002, for SCN and liver; Storch et al., 2002, for heart and liver; and Kornmann et al., 2001, for liver) are involved in different key cellular pathways such as metabolism, transcription, translation, protein turnover, cell cycle, cell death, vesicle trafficking, ion transport and signal transduction; which clearly underscore the importance of the circadian timing system for integrated physiology (Delaunay and Laudet, 2002).

The question arising from these findings is how the oscillatory expression of only a few canonical clock genes may regulate the oscillation of a high number of clockcontrolled genes (CCGs). There is evidence accounting for two mechanisms operating at the transcriptional level. One is the direct action of the CLOCK/BMAL1 heterodimer on CCGs transcription. This first possibility has been demonstrated for the rhythmic transcription of the gene encoding for the neuropeptide AVP in the SCN neurons. The CLOCK/BMAL1 heterodimer binds to Ebox DNA motifs located in the AVP gene promoter, thus upregulating AVP transcription (Fig. 3; Jin et al., 1999). However, it must be kept in mind that E-box motifs are also present in the promoter region of a large number of genes that do not follow a circadian pattern of expression. A comparative dissection of the context of the E-box motifs present in the promoter region of the circadian $A V P$ and non-circadian cyclin B1 genes, provided evidence for a strong influence of the E-box-flanking sequences in establishing robust circadian transcription driven by CLOCK/BMAL1 (Munoz et al., 2002). A second mechanism proposed is that the CLOCK/BMAL1 complex may act indirectly through the regulation of other CCGs that are in turn transcription factors. In support of this mechanism, it has been reported that the CLOCK/BMAL1 heterodimer induces expression of the DBP transcription factor, which in turn binds to the D-site located in the promoter region of different genes (Fig.
3). Thus, mice homozygous for a $D b p$ null allele, exhibit an altered circadian expression profile of some genes in the liver, such as steroid $15 \beta$ hydroxylase, coumarin 7 hydroxylase and cholesterol $7 \beta$ hydroxylase (Ripperger et al., 2000, and references therein). Considering that the CLOCK/ BMAL1 heterodimer as well as CCGs such as DBP and probably other proteins (particularly clock-related transcription factors; for instance, Rev-Erbo, E4BP4 and CREB, see above) may bind response elements in the promoter region of several genes, both mechanisms would explain the oscillation of a high number of genes in the SCN neurons and peripheral tissues. Thus, the fraction of the transcriptome that is oscillating at a given time seems to rely upon the coordinated expression and interaction of a number of gene products encoded by clock and clock-controlled genes.

\section{Peripheral clocks are responsible for overt circadian rhythms}

The early proposal that the circadian system is a hierarchy of biological clocks commanded by the SCN has been confirmed by recent studies showing in vivo oscillatory expression of clock genes in several tissues including other central nervous system components, termed peripheral clocks. There is evidence that SCN lesions might suppress rhythmic oscillation, but not the expression of $r P e r 2$ in the eye, brain, heart, lung, spleen, liver, and kidney (see Sakamoto et al., 1998), which is consistent with the concept of the circadian system being a hierarchical order of biological clocks.

In recent years, several authors have reported antiphase circadian expression of Bmall versus Perl and Per2 mRNAs in eye, heart, kidney and lung sampled from rat at different times of the day (Oishi et al., $1998 \mathrm{a}, \mathrm{b})$; whereas in the mouse, other authors described the oscillatory expression of the Per3 mRNA in liver, skeletal muscle and testis (Zylka et al., 1998) and of the Perl mRNA and PER1 protein in pars tuberalis (von Gall et al., 2002). However, the previous evidence of a circadian 
oscillation of clock genes in the testis has recently been challenged (Miyamoto et al., 1999; Fu et al., 2002; Alvarez et al., 2003; and Morse et al., 2003). Oscillation of Perl and Per 2 clock genes and Rev-Erb $\alpha, D B P$ and $T E F$ (thyrotroph embryonic factor) clock-controlled genes has also been demonstrated in cultured rat fibroblasts (Balsalobre et al., 1998). Using a NewWorld primate (capuchin monkey; Cebus apella) as a diurnal mammal experimental model, we have found expression of the clock genes Clock, Bmall and Per2 in the adrenal gland under in vivo and in vitro conditions (Richter et al., 2002; Valenzuela et al., 2003). As mentioned above, expression of clock genes has been documented in the heart and liver using microarrays. In peripheral oscillators, not only clock mRNAs, but also the encoded clock proteins have been shown to be expressed following high-amplitude rhythmic patterns over 24-h; for instance, in the liver, PER1, PER2, CRY1, CRY2 and BMAL1 proteins are rhythmically expressed (Lee et al., 2001). A consistent observation is that clock genes in the peripheral oscillators have a phase delay of 4-8-h relative to the SCN rhythm (see Balsalobre et al., 2000; Damiola et al., 2000; and Stokkan et al., 2001). Importantly, under culture conditions, the oscillatory process lasts for weeks in the $\mathrm{SCN}$ (i.e. it is self-sustained), whereas it dampens after a few cycles in peripheral tissues (i.e. it is not self-sustained). These findings indicate the existence of unknown but significant differences in the molecular mechanisms of circadian clock in the $\mathrm{SCN}$ and in peripheral tissues.

It has been suggested that instead of light, feeding may provide a time cue for some peripheral clocks. An interesting observation is that the phase displayed by clock genes in the liver, pancreas, kidney and heart is modified in rodents subjected to feeding restricted to a few hours every day (Balsalobre et al., 2000; Stokkan et al., 2001; Le Minh et al., 2001; Balsalobre, 2002). These animals increase both locomotor activity and core body temperature in anticipation of the timed daily meal. Such a food-anticipatory activity is controlled by a circadian clock as it persists when animals are food-deprived after some time of restricted feeding. The observation that a lesion of the SCN does not affect foodanticipatory activity suggests that there is a feeding-entrainable oscillator (FEO). A recent report provides evidence suggesting that NPAS2 (neuronal PAS domain protein 2, also named MOP4) expressed in the forebrain is essential for the full manifestation of food-anticipatory activity (Dudley et al., 2003). NPAS2 is expressed instead of CLOCK in the forebrain as transcriptional partner of BMAL1 (Reick et al., 2001; Dudley et al., 2003). As already mentioned, in previous papers the same group provided in vitro evidence for the transcriptional regulation of the clockwork mechanism by intracellular metabolic signals (Rutter et al., 2001). Consistent with the key role of the forebrain in food-anticipatory activity (Green and Menaker, 2003), Davidson et al. (2003) found no evidence of Perl expression in the gastrointestinal system in temporal correspondence with food-anticipatory activity. The in vivo feeding-derived resetting signal for FEO has not yet been identified, and it is possible that a number of blood-borne factors may act as endogenous zeitgebers integrated by the FEO (see Hirota et al., 2002, and references therein for discussion).

It is not known whether the neural connections of the SCN with the autonomous nervous system directly regulate clock gene expression in the pancreas, liver, heart, muscle (Kalsbeek and Buijs, 2002; Terazono et al., 2003) and adipose tissue (Kalsbeek et al., 2001), or whether the regulation is effected through SCN-driven humoral signals (Balsalobre, 2002). Glucocorticoids, a SCN-driven signal, modify the phase of clock genes expression in liver, pancreas, kidney and heart in animals subjected to restricted feeding conditions (Balsalobre et al., 2000) and in rat-1 fibroblasts (Balsalobre et al., 2000; Le Minh et al., 2001; Balsalobre, 2002). In fact, it has been shown that glucose (Hirota et al., 2002; rat-1 fibroblasts) and more generally, the redox state of the cells regulates the expression of clock genes (Rutter et al., 2001). 
The only evidence for regulation of a canonical clock gene by a SCN-driven hormone under in vivo conditions is the finding that in the mouse pars tuberalis the circadian expression of mPerl is dependent upon endogenous melatonin (von Gall et al., 2002). These authors studied the pars tuberalis of pinealectomized mice and found no oscillation of Perl expression, whereas the analysis of mice carrying a deletion of the melatonin receptor showed low levels of PER1 protein in the pars tuberalis. These results point to the possibility that melatonin may participate in the entrainment of a peripheral clock.

\section{Melatonin as a neuroendocrine transducer for circadian rhythms}

The possibility that melatonin plays a role as a neuroendocrine transducer between the SCN and some peripheral oscillators is being investigated. Plasma melatonin concentration exhibits a robust circadian rhythm. In diurnal and nocturnal species, the plasma melatonin rhythm is characterized by steadily low concentrations during light hours and high concentrations during darkness (Fig. 1; upper right panel). The duration of the daily increase in melatonin reflects the number of hours of darkness in the 24-h cycle and therefore signals the season of the year. Although local melatonin production has been demonstrated in several tissues (retina, digestive tract and testis; Tosini and Fukuhara, 2002; Messner et al., 2001; Tijmes et al., 1996; respectively), the circulating melatonin derives from the pineal organ (Lewy et al., 1980). The daily plasma melatonin rhythm depends on an intact $\mathrm{SCN}$ as demonstrated by its disappearance after the lesion of this nucleus (Meyer-Bernstein et al., 1999). A related finding is that a bright light pulse during dark hours quickly lowers the plasma melatonin concentration (Leproult et al., 2001). Also worth noticing is that the rhythm of plasma melatonin persists in some blind subjects and in animals maintained under constant dark conditions (Klerman et al., 2001; Illnerova, 1991; respectively), whereas it is suppressed in animals maintained in constant light (Torres-Farfan et al., 2004).

Melatonin receptors are present in central and peripheral tissues in the adult and also in the fetus. Melatonin acts through two $G$ protein-coupled membranebound receptor isoforms -MT1 and MT2and maybe on a nuclear receptor from the retinoic acid orphan receptors family, RZR/ ROR (Vanecek, 1998; and Carlberg and Wiesenberg, 1995; respectively). In the human, melatonin membrane-bound receptors are found in $\mathrm{SCN}$ and pars tuberalis, cerebellum, brain blood vessels, kidney and also prostate (Weaver et al., 1993; Al-Ghoul et al., 1998; Savaskan et al., 2001; Song et al, 1995; Laudon et al, 1996; respectively). A functional role in the regulation of steroidogenesis has been proposed for melatonin receptors in human granulosa cells, and capuchin monkey Leydig and adrenal gland cells (Woo et al., 2001; Valladares et al., 1997; and TorresFarfan et al., 2003; respectively).

The duration of the nocturnal melatonin peak reflects the duration of the photoperiod, that is, the short days that define winter result in long duration of the melatonin peak. The length of the nocturnal melatonin peak regulates the beginning of the reproductive season (Bartness et al., 1993; Lincoln et al., 2002). In seasonal breeders, such as hamsters and sheep, short days produce the opposite effects on reproduction. Gestation in hamsters takes 2 weeks, and reproduction is stimulated by long days. In contrast, sheep, which have a 21-week gestation period, short days gate reproduction. In this way, both species give birth in spring.

An important variable related to seasonal reproduction is plasma prolactin concentration. In sheep, plasma prolactin concentration is maximal in summer (coinciding with reproductive quiescence) and minimal in winter, in which most animals are already pregnant. The following lines of evidence - derived from in vivo experiments - have prompted the suggestion that the impact of melatonin on the pars tuberalis of the pituitary stalk mediate the effects of photoperiod on prolactin secretion in seasonal mammals: prolactin 
levels increase in response to reduced melatonin levels; seasonal cycles of prolactin depend on an intact pars tuberalis, but not on the hypothalamic-pituitary connection; and MT1 melatonin receptors are present at a high density in the pars tuberalis (Lincoln et al., 2002, and references therein). The possibility that this region may operate as a transducer of photoperiod information carried by melatonin in an endocrine output signal is reinforced by data on melatonin-dependent secretion of tuberalins (putative pars tuberalis-specific hormones), which in turn may regulate secretion of PRL and other pituitary hormones (Guerra and Rodríguez, 2001, 2002). In the sheep pars tuberalis, analysis of the temporal expression pattern of seven clock genes by means of in situ hybridization showed high-amplitude 24-h rhythmic cycles in the expression of Bmall, Clock, Per1, Per2, Cryl and Cry2, but not of casein kinase IE. Furthermore, the pattern of expression of these genes in othe 24-h cycle was different between summer and winter photoperiods (Lincoln et al., 2002). These data agree with the already mentioned observation that in mouse pars tuberalis the circadian expression of the Perl clock gene is melatonin-dependent (von Gall et al., 2002).

Whether similar actions of melatonin may take place in other tissues is presently unknown. As mentioned, we have recently reported the expression of functional MT1 melatonin receptors in the adult capuchin monkey adrenal cortex (Torres-Farfán et al., 2003), which is the first evidence for the expression of this receptor in the adrenal gland of a mammalian species. In this report, in vitro evidence was obtained for the inhibition of ACTH-stimulated cortisol production by melatonin. We were able to detect the expression of clock genes in this tissue by using semiquantitative (Richter et al., 2002; Valenzuela et al., 2003) and real-time (unpublished results) RT-PCR and are currently analyzing their oscillatory pattern in the 24-h period under in vivo and in vitro conditions. We are also currently testing the hypothesis that melatonin may regulate the phase of the daily expression of these genes in the putative peripheral clock contained in the adrenal gland of adult primates.

The pineal gland of mammalian fetuses, including the human, does not secrete melatonin, although melatonin may play an important role in the entrainment of fetal clocks, given that fetuses are exposed to the maternal melatonin rhythm through the placenta (Fig. 1, upper right panel; Yellon and Longo, 1987; McMillen and Nowak, 1989; Kennaway et al., 1992). This avenue for melatonin to mediate functional interactions between maternal and fetal physiology has been explored at the level of the fetal SCN (Naitoh et al., 1998) and control of fetal circadian rhythms (Houghton et al., 1993; Serón-Ferré et al., 1989, 1993, 2002). Nonetheless, maternal melatonin may be also involved in direct regulation of fetal peripheral clocks given the presence of melatonin receptors not only in the fetal SCN (see above), but also in diverse tissues of the developing sheep (Helliwell and Williams, 1994), as well as in human fetal kidney (Drew et al., 1998) and in non-human primate fetal adrenal gland (Torres-Farfán et al., in press). We have recently detected expression of clock genes (Bmal1, Clock, Per2 and Cry2) in the fetal SCN and adrenal gland of the capuchin monkey (Rocco et al., 2003).

\section{Concluding remarks}

Evolution has produced predictive adaptations to take advantage of the reproducible day/night changes imposed by the Earth's rotation. In mammals this adaptation involves the existence of a master clock that induces temporal order in the complex network of physiological and behavioral variables. The recent confirmation of the existence of peripheral clocks in a number of cell types and tissues shed light on the previously inferred hierarchical order of the circadian timekeeping system, and also provided a view of the way in which different circadian physiological and behavioral variables are commanded by the SCN through neural and/ or humoral signals. The efforts to understand this circadian timing system have greatly 
profited from studies that integrate molecular aspects to the systems and behavioral levels of analysis. A fascinating finding is that disturbed expression pattern of one clock gene results in profound effects at the whole-organism level. The use of genome-wide tools for the analysis of biological clocks has rendered evidence indicating that circadian oscillation is an ubiquitous aspect of cellular regulation and that approximately $10 \%$ of the transcriptome is oscillating at any given time. Of note, the vast majority of the hundreds of genes found to follow a circadian pattern of expression in the SCN and peripheral tissues remains to be linked to the clockwork oscillatory mechanism. Further genomic and postgenomic analyses, with particular emphasis on the full characterization of the promoter region of clock and key clockcontrolled genes, will help to better understand the connections between clock genes and overt circadian behavior.

A better understanding of the human circadian system will have direct consequences on public health. Human circadian-related sleep disorders are observed as a consequence of jet lag, as well as in shift workers and the blind. Our modern society has imposed rotational shift-working schedules upon some $25 \%$ of the population, and particular care must be paid to the prevalence of chronic illness and industrial accidents, which strongly emphasizes our need for temporal stability (Hastings, 2000). In this context, it is disturbing that experiments with flies have shown that constant shifting shortens life expectancy by more than 20\% (Aschoff et al., 1971). The development of the circadian time-keeping system during intrauterine life is incompletely understood, and negative implications may arise in pre-term newborns, that abruptly trade a circadian environment controlled by maternal signals for a timeless Intensive Care Unit room. Studies on the circadian system, bringing together all biological levels of analysis, from the molecular to the sociological, will continue to provide a common framework that will help us understand our relation with Mother Earth.

\section{ACKNOWLEDGMENTS}

We thank M. Guerra for useful discussions and comments on the manuscript. This work was supported by grants 2010140, Líneas Complementarias 8980006 and 1030425 from FONDECYT, Chile, and a grant from San Bernardino Medical Foundation (Colton, CA, USA). P.P.R-G. was a postdoctoral fellow from PROGRESAR Foundation, and C.T-F. is a PhD-student fellow from DIPUC (Pontificia Universidad Católica de Chile).

\section{REFERENCES}

AL-GHOUL WM, HERMAN MD, DUBOCOVICH ML (1998) Melatonin receptor subtype expression in human cerebellum. Neuroreport 9: 4063-4068

ÁLVAREZ JD, CHEN D, STORER E, SEHGAL A (2003) Non-cyclic and developmental stage-specific expression of circadian clock proteins during murine spermatogenesis. Biol Reprod 69: 81-91

ARCHER SN, ROBILLIARD DL, SKENE DJ, SMITS M, WILLIAMS A, ARENDT J, VON SCHANTZ M (2003) A length polymorphism in the circadian clock gene Per3 is linked to delayed sleep phase syndrome and extreme diurnal preference. Sleep 26: 413-415

ASCHOFF J, VON SAINT PAUL U, WEVER R (1971) Lifetime of flies under influence of time displacement. Naturwissenschaften 58: 574

BALSALOBRE A, DAMIOLA F, SCHIBLER U (1998) A serum shock induces circadian gene expression in mammalian tissue culture cells. Cell 93: 929-937

BALSALOBRE A, BROWN SA, MARCACCI L, TRONCHE F, KELLENDONK C, REICHARDT HM, SCHÜTZ G, SCHIBLER U (2000) Resetting of circadian time in peripheral tissues by glucocorticoid signaling. Science 289: 2344-2347

BALSALOBRE A (2002) Clock genes in mammalian peripheral tissues. Cell Tissue Res 309: 193-199

BARTNESS TJ, POWERS JB, HASTINGS MH, BITTMAN EL, GOLDMAN BD (1993) The timed infusion paradigm for melatonin delivery: what has it taught us about the melatonin signal, its reception, and the photoperiodic control of seasonal responses? J Pineal Res 15: 161-190

BELANGER PM, BRUGUEROLLE B, LABRECQUE G (1997) Rhythms in pharmaco kinetics; absorption, distribution, metabolism and excretion. In: REDFERN PH, LEMMER B (Eds), Physiology and pharmacology of biological rhythms, Springer-Verlag, Berlin, Heidelberg, New York. Pp: 177-204

BERSON DM, DUNN FA, TAKAO M (2002) Phototransduction by retinal ganglion cells that set the circadian clock. Science 295: 1070-1073

BUIJS RM, WORTEL J, VAN HEERIKHUIZE JJ, FEENSTRA MG, TER HORST GJ, ROMIJN HJ, KALSBEEK A (1999) Anatomical and functional demonstration of a multisynaptic suprachiasmatic nucleus adrenal (cortex) pathway. Eur J Neurosci 11: 1535-1544

CARLBERG C, WIESENBERG I (1995) The orphan receptor family RZR/ROR, melatonin and 5lipoxygenase: an unexpected relationship. J Pineal Res 18: $171-178$ 
CHENG MY, BULLOCK CM, LI C, LEE AG, BERMAK JC, BELLUZZI J, WEAVER DR, LESLIE FM, ZHOU QY (2002) Prokineticin 2 transmits the behavioural circadian rhythm of the suprachiasmatic nucleus. Nature 417: 405-410

COHEN RA, ALBERS HE (1991) Disruption of human circadian and cognitive regulation following a discrete hypothalamic lesion: a case study. Neurology 41: 726-729

CROSIO C, CERMAKIAN N, ALLIS C D, SASSONECORSI P (2000) Light induces chromatin modification in cells of the mammalian circadian clock. Nat Neurosci 3: 1241-1247

CURTIS AM, SEO SB, WESTGATE EJ, RUDIC RD, SMYTH EM, CHAKRAVARTI D, FITZGERALD GA, MCNAMARA P (2003) HAT-dependent chromatin remodeling and the vascular clock. J Biol Chem, in press (Nov 26 Epub ahead of print)

DAMIOLA F, LE MINH N, PREITNER N, KORNMANN B, FLEURY-OLELA F, SCHIBLER U (2000) Restricted feeding uncouples circadian oscillators in peripheral tissues from the central pacemaker in the suprachiasmatic nucleus. Genes Dev 14: 2950-2961

DAVIDSON AJ, POOLE AS, YAMAZAKI S, MENAKER M (2003) Is the food-entrainable circadian oscillator in the digestive system? Genes Brain Behav 2: 32-39

DAVIS FC, MANNION J (1988) Entrainment of hamster pup circadian rhythms by prenatal melatonin injections to the mother. Am J Physiol 255: R439-R448

DECOURSEY PJ, BUGGY J (1989) Circadian rhythmicity after neural transplant to hamster third ventricle: specificity of suprachiasmatic nuclei. Brain Res 500: 263-275

DE LA IGLESIA HO, MEYER J, SCHWARTZ WJ (2003) Lateralization of circadian pacemaker output: activation of left- and right- sided luteinizing hormonereleaseing hormone neurons involves a neural rather than a humoral pathway. J Neurosci 23: 7412-7414

DELAUNAY F, LAUDET V (2002) Circadian clock and microarrays: mammalian genome gets rhythm. Trends Genet 18: 595-597

DOI M, NAKAJIMA Y, OKANO T, FUKADA Y (2001) Light-induced phase-delay of the chicken pineal circadian clock is associated with the induction of cE4bp4, a potential transcriptional repressor of cPer2 gene. Proc Natl Acad Sci USA 98: 8089-8094

DREW JE, WILLIAMS LM, HANNAH LT, BARRETT P, ABRAMOVICH DR (1998) Melatonin receptors in the human fetal kidney: 2-[125I]iodomelatonin binding sites correlated with expression of Mel1a and Mel1b receptor genes. J Endocrinol 156: 261-267

DUDLEY CA, ERBEL-SIELER C, ESTILL SJ, REICK M, FRANKEN P, PITTS S, McKNIGHT SL (2003) Altered patterns of sleep and behavioral adaptability in NPAS2-deficient mice. Science 301: 379-383

DUNLAP JC (1999) Molecular bases of circadian clocks. Cell 96: 271-290

EARNEST DJ, IADAROLA M, YEH HH, OLSCHOWKA JA (1990) Photic regulation of c- fos expression in neural components governing the entrainment of circadian rhythms. Exp Neurol 109: 353-361

EDERY I (2000) Circadian rhythms in a nutshell. Physiol Genomics 3: 59-74

ENRIGHT JT (1981) Methodology. In: Aschoff J (Ed), Handbook of behavioral neurobiology, volume 4: biological rhythms, Plenum Press, New York NY. Pp: 11-19

ETCHEGARAY JP, LEE C, WADE PA, REPPERT SM (2003) Rhythmic histone acetylation underlies transcription in the mammalian circadian clock. Nature 421: $177-182$
FREEDMAN MS, LUCAS RJ, SONI B, VON SCHANTZ M, MUNOZ M, DAVID-GRAY Z, FOSTER R (1999) Regulation of mammalian circadian behavior by non-rod, non-cone, ocular photoreceptors. Science 284: 502-504

FU Z, INABA M, NOGUCHI T, KATO H (2002) Molecular cloning and circadian regulation of cryptochrome genes in Japanese quail (Coturnix coturnix japonica). J Biol Rhythms 17: 14-27

GANGULY S, COON SL, KLEIN DC (2002) Control of melatonin synthesis in the mammalian pineal gland: the critical role of serotonin acetylation. Cell Tissue Res 309: 127-137

GAU D, LEMBERGER T, VON GALL C, KRETZ O, LE MINH N, GASS P, SCHMID W, SCHIBLER U, KORF HW, SCHUTZ G (2002) Phosphorylation of CREB Ser142 regulates light-induced phase shifts of the circadian clock. Neuron 34: 245-253

GILLETTE MU, PROSSER RA (1988) Circadian rhythm of the rat suprachiasmatic brain slice is rapidly reset by daytime application of cAMP analogs. Brain Res 474: 348-352

GINTY DD, KORNHAUSER JM, THOMPSON MA, BADING H, MAYO KE, TAKAHASHI JS, GREENBERG ME (1993) Regulation of CREB phosphorylation in the suprachiasmatic nucleus by light and a circadian clock. Science 260: 238-241

GLATTRE E, BJERKEDAL T (1983) The 24-hour rhythmicity of birth. A populational study. Acta Obstet Gynecol Scand 62: 31-36

GOLD DR, ROGACZ S, BOCK N, TOSTESON TD, BAUM TM, SPEIZER FE, CZEISLER CA (1992) Rotating shift work, sleep, and accidents related to sleepiness in hospital nurses. Am J Public Health 82: 1011-1014

GOOLEY JJ, LU J, FISCHER D, SAPER CB (2003) A broad role for melanopsin in nonvisual photoreception. J Neurosci 23: 7093-7106

GREEN CB, MENAKER M (2003) Clocks on the brain. Science 301: 319-320

GUERRA M, RODRÍGUEZ EM (2001) Identification, cellular and subcellular distribution of 21 and $72 \mathrm{kDa}$ proteins (tuberalins?) secreted by specific cells of the pars tuberalis. J Endocrinol 168: 363-379

GUERRA M, RODRÍGUEZ EM (2002) New evidence for a pineal -pars tuberalis- pars distalis axis. In: KELLER R, DIRCKSEN H, SEDLMEIER, VAUDRY H (Eds), Proceedings of the 21st Conference of European Comparative Endocrinologists, International Proceedings Division, Bonn, Germany. Pp: 123-127

HANNIBAL J (2002) Neurotransmitters of the retinohypothalamic tract. Cell Tissue Res 309: 73-88

HAO H, RIVKEES SA (1999) The biological clock of very premature primate infants is responsive to light. Proc Natl Acad Sci USA 96: 2426-2429

HASTINGS MH (2000) Circadian clockwork: two loops are better than one. Nat Rev Neurosci 1: 143-146

HATTAR S, LIAO HW, TAKAO M, BERSON DM, YAW KW (2002) Melanopsin-containing retinal ganglion cells: architcture, projections, and intrinsic photosensitivity. Science 295: 1065-1070

HELLIWELL RJ, WILLIAMS LM (1994) The development of melatonin-binding sites in the ovine fetus. J Endocrinol 142: 475-484

HIROTA T, OKANO T, KOKAME K, SHIROTANIIKEJIMA H, MIYATA T, FUKADA Y (2002) Glucose down-regulates Per1 and Per2 mRNA levels and induces circadian gene expression in cultured Rat-1 fibroblasts. J Biol Chem 277: 44244-44251

HONMA S, KAWAMOTO T, TAKAGI Y, FUJIMOTO K, SATO F, NOSHIRO M, KATO Y, HONMA K (2002) 
Dec1 and Dec2 are regulators of the mammalian molecular clock. Nature 419: 841-844

HOUGHTON DC, WALKER DW, YOUNG IR, MCMILLEN IC (1993) Melatonin and the light-dark cycle separately influence daily behavioral and hormonal rhythms in the pregnant ewe and sheep fetus. Endocrinology 133: 90-98

ILLNEROVA H (1991) The suprachiasmatic nucleus and rhythmic pineal melatonin production. In: KLEIN DC, MOORE RY, REPPERT SM (Eds), Suprachiasmatic nucleus, the mind's clock, Oxford University Press, Oxford, NY. Pp: 197-216

JIN X, SHEARMAN LP, WEAVER DR, ZYLKA MJ, DE VRIES GJ, REPPERT SM (1999) A molecular mechanism regulating rhythmic output from the suprachiasmatic circadian clock. Cell 96: 57-68

KALSBEEK A, FLIERS E, ROMIJN JA, LA FLEUR SE, WORTEL J, BAKKER O, ENDERT E, BUIJS RM (2001) The suprachiasmatic nucleus generates the diurnal changes in plasma leptin levels. Endocrinology 142: $2677-2685$

KALSBEEK A, BUIJS RM (2002) Output pathways of the mammalian suprachiasmatic nucleus: coding circadian time by transmitter selection and specific targeting. Cell Tissue Res 309: 109-118

KATZENBERG D, YOUNG T, FINN L, LIN L, KING DP, TAKAHASHI JS, MIGNOT E (1998) A CLOCK polymorphism associated with human diurnal preference. Sleep 21: 569-576

KATZENBERG D, YOUNG T, LIN L, FINN L, MIGNOT E (1999) A human period gene (HPER1) polymorphism is not associated with diurnal preference in normal adults. Psychiatr Genet 9: 107-109

KENNAWAY DJ, STAMP GE, GOBLE FC (1992) Development of melatonin production in infants and the impact of prematurity. J Clin Endocrinol Metab 75: 367-369

KLERMAN EB, ZEITZER JM, DUFFY JF, KHALSA SB, CZEISLER CA (2001) Absence of an increase in the duration of the circadian melatonin secretory episode in totally blind human subjects. J Clin Endocrinol Metab 86: 3166-3170

KORNMANN B, PREITNER N, RIFAT D, FLEURYOLELA F, SCHIBLER U (2001) Analysis of circadian liver gene expression by ADDER, a highly sensitive method for the display of differentially expressed mRNAs. Nucleic Acids Res 29: E51-E61

KUBOTA A, INOUYE ST, KAWAMURA H (1981) Reversal of multiunit activity within and outside the suprachiasmatic nucleus in the rat. Neurosci Lett 27: 303-308

LAUDON M, GILAD E, MATZKIN H, BRAF Z, ZISAPEL N (1996) Putative melatonin receptors in benign human prostate tissue. J Clin Endocrinol Metab 81: 1336-1342

LEE C, ETCHEGARAY JP, CAGAMPANG FR, LOUDON AS, REPPERT SM (2001) Posttranslational mechanisms regulate the mammalian circadian clock. Cell 107: 855-867

LE MINH N, DAMIOLA F, TRONCHE F, SCHUTZ G, SCHIBLER U (2001) Glucocorticoid hormones inhibit food-induced phase-shifting of peripheral circadian oscillators. EMBO J 20: 7128-7136

LEPROULT R, COLECCHIA EF, L'HERMITEBALERIAUX M, VAN CAUTER E (2001) Transition from dim to bright light in the morning induces an immediate elevation of cortisol levels. J Clin Endocrinol Metab 86: 151-157

LEVI F (1997) Chronopharmacology of anticancer agents. In: REDFERN PH, LEMMER B (Eds), Physiology and pharmacology of biological rhythms, Springer-Verlag, Berlin, Heidelberg, New York. Pp: 299-331

LEWY AJ, TETSUO M, MARKEY SP, GOODWIN FK, KOPIN IJ (1980) Pinealectomy abolishes plasma melatonin in the rat. J Clin Endocrinol Metab 50: 204 205

LINCOLN G, MESSAGER S, ANDERSSON $\mathrm{H}$ HAZLERIGG D (2002) Temporal expression of seven clock genes in the suprachiasmatic nucleus and the pars tuberalis of the sheep: evidence for an internal coincidence timer. Proc Natl Acad Sci USA 99: 1389013895

LÓPEZ-MOLINA L, CONQUET F, DUBOIS-DAUPHIN M, SCHIBLER U (1997) The DBP gene is expressed according to a circadian rhythm in the suprachiasmatic nucleus and influences circadian behavior. EMBO J 16: 6762-6771

LOWREY PL, SHIMOMURA K, ANTOCH MP, YAMAZAKI S, ZEMENIDES PD, RALPH MR, MENAKER M, TAKAHASHI JS (2000) Positional syntenic cloning and functional characterization of the mammalian circadian mutation tau. Science 288: 483-492

MAYWOOD ES, O'BRIEN JA, HASTINGS MH (2003) Expression of mCLOCK and other circadian clockrelevant proteins in the mouse suprachiasmatic nuclei. J Neuroendocrinol 15: 329-334

McMILLEN IC, NOWAK R (1989) Maternal pinealectomy abolishes the diurnal rhythm in plasma melatonin concentrations in the fetal sheep and pregnant ewe during late gestation. J Endocrinol 120: 459-464

MESSNER M, HUETHER G, LORF T, RAMADORI G, SCHWORER H (2001) Presence of melatonin in the human hepatobiliary-gastrointestinal tract. Life Sci 69: 543-551

MEYER-BERNSTEIN EL, JETTON AE, MATSUMOTO S-I, MARKUNS JF, LEHMAN MN, BITTMAN EL (1999) Effects of suprachiasmatic transplants on circadian rhythms of neuroendocrine function in golden hamsters. Endocrinology 140: 207-218

MIYAMOTO Y, SANCAR A (1999) Circadian regulation of cryptochrome genes in the mouse. Brain Res Mol Brain Res 71: 238-243

MOORE RY, EICHLER VB (1972) Loss of circadian adrenal corticosterone rhythm following suprachiasmatic nucleus lesions in the rat. Brain Res 42: 201-206

MOORE RY, SPEH JC, LEAK RK (2002) Suprachiasmatic nucleus organization. Cell Tissue Res 309: 89-98

MOORE-EDE MC, SULZMAN FM, FULLER CA (1982) The clocks that time us. Harvard University Press, Cambridge MA. Pp: 30-133

MORSE D, CERMAKIAN N, BRANCORSINI S, PARVINEN M, SASSONE-CORSI P (2003) No Circadian Rhythms in Testis: Period1 Expression Is Clock Independent and Developmentally Regulated in the Mouse. Mol Endocrinol 17: 141-151

MULLER C, TORREALBA F (1998) Postnatal development of neuron number and connections in the suprachiasmatic nucleus of the hamster. Dev Brain Res 110: 203-213

MUNOZ E, BREWER M, BALER R (2002) Circadian Transcription. Thinking outside the E-Box. J Biol Chem 277: 36009-36017

NAITOH N, WATANABE Y, MATSUMURA K, MURAI I, KOBAYASHI K, IMAI-MATSUMURA K, OHTUKA H, TAKAGI K, MIYAKE Y, SATOH K, WATANABE Y (1998) Alteration by maternal pinealectomy of fetal and neonatal melatonin and dopamine D1 receptor binding in the suprachiasmatic nuclei. Biochem Biophys Res Commun 253: 850-854 
OISHI $\mathrm{K}$, SAKAMOTO $\mathrm{K}$, OKADA T, NAGASE T, ISHIDA N (1998a) Antiphase circadian expression between BMAL1 and period homologue mRNA in the suprachiasmatic nucleus and peripheral tissues of rats. Biochem Biophys Res Commun 253: 199-203

OISHI K, SAKAMOTO K, OKADA T, NAGASE T, ISHIDA N (1998b) Humoral signals mediate the circadian expression of rat period homologue (rPer2) mRNA in peripheral tissues. Neurosci Lett 256: 117119

OKAMURA H, YAMAGUCHI S, YAGITA K (2002) Molecular machinery of the circadian clock in mammals. Cell Tissue Res 309: 47-56

PANDA S, SATO TK, CASTRUCCI AM, ROLLAG MD, DEGRIP WJ, HOGENESCH JB, PROVENCIO I, KAY SA (2002a) Melanopsin (Opn4) requirement for normal light-induced circadian phase shifting. Science 298: 2213-2216

PANDA S, ANTOCH MP, MILLER BH, SU AI, SCHOOK AB, STRAUME M, SCHULTZ PG, KAY SA, TAKAHASHI JS, HOGENESCH JB (2002b) Coordinated transcription of key pathways in the mouse by the circadian clock. Cell 109: 307-320

PARRAGUEZ VH, SALES F, VALENZUELA GJ, VERGARA M, CATALÁN L, SERON-FERRE M (1998) Diurnal changes in light intensity inside the pregnant uterus in sheep. Anim Reprod Sci 52: 123-130

RALPH MR, MENAKER M (1988) A mutation of the circadian system in golden hamsters. Science 241 : $1225-1227$

RALPH MR, FOSTER RG, DAVIS FC, MENAKER M (1990) Transplanted suprachiasmatic nucleus determines circadian period. Science 247:975-978

REICK M, GARCÍA JA, DUDLEY C, McKNIGHT SL (2001) NPAS2: an analog of clock operative in the mammalian forebrain. Science 293: 506-509

RENSING L (1997) Genetics and molecular biology of circadian clocks. In: REDFERN PH, LEMMER B (Eds), Physiology and pharmacology of biological rhythms, Springer-Verlag, Berlin, Heidelberg, New York. Pp: 55-77

REPPERT SM, WEAVER DR, RIVKEES SA, STOPA EG (1988) Putative melatonin receptors in a human biological clock. Science 242: 78-81

REPPERT SM, WEAVER DR (2002) Coordination of circadian timing in mammals. Nature 418: 935-941

RICHTER HG, TORRES-FARFÁN C, ROJAS-GARCÍA P, TORREALBA F, VALENZUELA G, CAMPINO C, SERÓN-FERRÉ M (2002) Expression of clock genes in the primate adrenal gland: a new peripheral clock? Reunion Conjunta 2002: Sociedades Chilenas de Ciencias Fisiologicas y de Farmacologia, La Serena, Chile, Septiembre 23-26 (full text available at: http:// codon.ciencias.uchile.cl/ csfisiol/serena/73.pdf)

RIPPERGER JA, SHEARMAN LP, REPPERT SM, SCHIBLER U (2000) CLOCK, an essential pacemaker component, controls expression of the circadian transcription factor DBP. Genes Dev 14: 679-689

RIVKEES SA, LACHOWICZ JE (1997) Functional D1 and D5 dopamine receptors are expressed in the suprachiasmatic, supraoptic, and paraventricular nuclei of primates. Synapse 26: 1-10

ROCCO V, VALENZUELA FJ, VIALE L, TORRESFARFÁN C, GERMAIN AM, CAMPINO C, TORREALBA F， SERÓN-FERRÉ M (2003) Transcription of clock genes in the fetal suprachiasmatic nucleus and adrenal gland of the capuchin monkey. Preliminary results. XVIII Reunion Sociedad Chilena de Ciencias Fisiologicas, Villa Alemana, Chile, Octubre 2-4 (full text available at: http://codon.ciencias.uchile.cl/ csfisiol/ValleDorado/ P48.pdf)

RUBY NF, BRENNAN TJ, XIE X, CAO V, FRANKEN P, HELLER HC, O'HARA BF (2002) Role of melanopsin in circadian responses to light. Science 298: 2211-2213

RUTTER J, REICK M, WU LC, MCKNIGHT SL (2001) Regulation of clock and NPAS2 DNA binding by the redox state of NAD cofactors. Science 293: 510-514

SAKAMOTO K, NAGASE T, FUKUI H, HORIKAWA K, OKADA T, TANAKA $\mathrm{H}$, SATO K, MIYAKE Y, OHARA O, KAKO K, ISHIDA N (1998) Multitissue circadian expression of rat period homolog (rPer2) mRNA is governed by the mammalian circadian clock, the suprachiasmatic nucleus in the brain. J Biol Chem 273: 27039-27042

SAVASKAN E, OLIVIERI G, BRYDON L, JOCKERS R, KRAUCHI K, WIRZ-JUSTICE A, MULLER-SPAHN F (2001) Cerebrovascular melatonin MT1-receptor alterations in patients with Alzheimer's disease. Neurosci Lett 308: 9-12

SCHWARTZ WJ, BUSIS NA, HEDLEY-WHYTE ET (1986) A discrete lesion of ventral hypothalamus and optic chiasm that disturbed the daily temperature rhythm. J Neurol 233: 1-4

SCHWARTZ WJ (1991) SCN metabolic activity in vivo. In: KLEIN DC, MOORE RY, REPPERT SM (Eds), Suprachiasmatic nucleus the mind's clock, Oxford University Press, New York NY. Pp: 144-156

SERÓN-FERRÉ M, VERGARA M, PARRAGUEZ VH, RIQUELME R, LLANOS AJ (1989) Fetal prolactin levels respond to a maternal melatonin implant. Endocrinology 125: 400-403

SERÓN-FERRÉ M, DUCSAY CA, AND VALENZUELA GJ (1993) Circadian rhythms during pregnancy. Endocr Rev 14: 594-609

SERÓN-FERRÉ M, TORRES C, PARRAGUEZ VH, VERGARA M, VALLADARES L, FORCELLEDO ML, CONSTANDIL L, VALENZUELA GJ (2002) Perinatal neuroendocrine regulation. Development of the circadian time-keeping system. Mol Cell Endocrinol 186: 169-173

SHEARMAN LP, JIN $X$, LEE C, REPPERT SM, WEAVER DR (2000a) Targeted disruption of the mPer3 gene: subtle effects on circadian clock function. Mol Cell Biol 20: 6269-6275

SHEARMAN LP, SRIRAM S, WEAVER DR, MAYWOOD ES, CHAVES I, ZHENG B, KUME K, LEE CC, VAN DER HORST GT, HASTINGS MH, REPPERT SM (2000b) Interacting molecular loops in the mammalian circadian clock. Science 288: 1013-1019

SILVER R, LESAUTER J, TRESCO PA, LEHMAN MN (1996) A diffusible coupling signal from the transplanted suprachiasmatic nucleus controlling circadian locomotor rhythms. Nature 382: 810-813

SONG Y, TAM PC, POON AM, BROWN GM, PANG SF (1995) 2-[125I]iodomelatonin-binding sites in the human kidney and the effect of guanosine 5'-O-(3thiotriphosphate). J Clin Endocrinol Metab 80: 15601565

STEPHAN FK, ZUCKER I (1972) Circadian rhythms in drinking behavior and locomotor activity of rats are eliminated by hypothalamic lesions. Proc Natl Acad Sci USA 69: 1583-1586

STOKKAN KA, YAMAZAKI S, TEI H, SAKAKI Y, MENAKER M (2001) Entrainment of the circadian clock in the liver by feeding. Science 291: 490-493

STORCH KF, LIPAN O, LEYKIN I, VISWANATHAN N, DAVIS FC, WONG WH, WEITZ CJ (2002) Extensive and divergent circadian gene expression in liver and heart. Nature 417:78-83 
TAMARU T, ISOJIMA Y, YAMADA T, OKADA M, NAGAI K, TAKAMATSU K (2000) Light and glutamate-induced degradation of the circadian oscillating protein BMAL1 during the mammalian clock resetting. J Neurosci 20: 7525-7530

TERAZONO H, MUTOH T, YAMAGUCHI S, KOBAYASHI M, AKIYAMA M, UDO R, OHDO S, OKAMURA H, SHIBATA S (2003) Adrenergic regulation of clock gene expression in mouse liver. Proc Natl Acad Sci USA. 100: 6795-6800

TIJMES M, PEDRAZA R, VALLADARES L (1996) Melatonin in the rat testis: evidence for local synthesis. Steroids 61: 65-68

TOH KL, JONES CR, HE Y, EIDE EJ, HINZ WA, VIRSHUP DM, PTACEK LJ, FU YH (2001) An hPer2 phosphorylation site mutation in familial advanced sleep phase syndrome. Science 291: 1040-1043

TORREALBA F, PARRAGUEZ VH, REYES T, VALENZUELA G, SERÓN-FERRÉ M (1993) Prenatal development of the retinohypothalamic pathway and the suprachiasmatic nucleus in the sheep. J Comp Neurol 338: 304-316

TORRES-FARFÁN C, RICHTER HG, ROJAS-GARCÍA P, VERGARA M, FORCELLEDO ML, VALLADARES LE, TORREALBA F, VALENZUELA GJ AND SERÓN-FERRÉ M (2003) mt1 melatonin receptor activation inhibits ACTH-stimulated cortisol production in the adrenal gland of capuchin monkey (Cebus apella). J Clin Endocrinol Metab 88: 450-458

TORRES-FARFÁN C, RICHTER HG, GERMAIN AM, VALENZUELA GJ, CAMPINO C, ROJAS-GARCÍA P, FORCELLEDO ML, TORREALBA F, SERÓNFERRÉ M. 2004 Maternal melatonin selectively inhibits cortisol production in the primate fetal adrenal gland. J Physiol, 554: $841-856$.

TOSINI G, FUKUHARA C (2002) The mammalian retina as a clock. Cell Tissue Res 309: 119-126

TRAVNICKOVA-BENDOVA Z, CERMAKIAN N, REPPERT SM, SASSONE-CORSI P (2002) Bimodal regulation of mPeriod promoters by CREB-dependent signaling and CLOCK/BMAL1 activity. Proc Natl Acad Sci USA 99: 7728-7733

UEDA HR, CHEN W, ADACHI A, WAKAMATSU H, HAYASHI S, TAKASUGI T, NAGANO M, NAKAHAMA K, SUZUKI Y, SUGANO S, IINO M, SHIGEYOSHI Y, HASHIMOTO S (2002) A transcription factor response element for gene expression during circadian night. Nature 418: 534-539

VALENZUELA F, RICHTER H, VIALE L, TORRESFARFÁN C, SERÓN-FERRÉ M (2003) Oscillatory expression of clock genes in the adult capuchin monkey adrenal gland. XVIII Reunion Sociedad Chilena de Ciencias Fisiologicas, Villa Alemana, Chile, Octubre 2-4 (full text available at: http:// codon.ciencias.uchile.cl/ csfisiol/ValleDorado/ P37.pdf)

VALLADARES L, PINO A, RECABARREN M, ROJAS P, MOYA V, SERÓN-FERRÉ M (1997) Melatonina y función endocrina reproductiva: caracterización de un receptor de melatonina en primates. 15th ALIRH Meeting, Cuzco, Peru. Pp: 48

VANECEK J (1998) Cellular mechanisms of melatonin action. Physiol Rev 78: 687-721

VISWANATHAN N, WEAVER DR, REPPERT SM, DAVIS FC (1994) Entrainment of the fetal hamster circadian pacemaker by prenatal injections of the dopamine agonist SKF 38393. J Neurosci 14: 53935398

VON GALL C, GARABETTE ML, KELL CA, FRENZEL S, DEHGHANI F, SCHUMM-DRAEGER PM, WEAVER DR, KORF HW, HASTINGS MH, STEHLE JH (2002) Rhythmic gene expression in pituitary depends on heterologous sensitization by the neurohormone melatonin. Nat Neurosci 5: 234-238

VON GALL C, NOTON E, LEE C, WEAVER DR (2003) Light does not degrade the constitutively expressed BMAL1 protein in the mouse suprachiasmatic nucleus. Eur J Neurosci 18: 125-133

WEAVER DR, STEHLE JH, STOPA EG, REPPERT SM (1993) Melatonin receptors in human hypothalamus and pituitary: implications for circadian and reproductive responses to melatonin. J Clin Endocrinol Metab 76: 295-301

WELSH DK, LOGOTHETIS DE, MEISTER M, REPPERT SM (1995) Neurons dissociated from rat suprachiasmatic nucleus express independently phased circadian firing rhythms. Neuron 14: 697-706

WOO MM, TAI CJ, KANG SK, NATHWANI PS, PANG SF, LEUNG PC (2001) Direct action of melatonin in human granulosa-luteal cells. J Clin Endocrinol Metab 86: 4789-4797

YAMAZAKI S, KERBESHIAN MC, HOCKER CG, BLOCK GD, MENAKER M (1998) Rhythmic properties of the hamster suprachiasmatic nucleus in vivo. J Neurosci 18: 10709-10723

YELLON SM, LONGO LD (1987) Melatonin rhythms in fetal and maternal circulation during pregnancy in sheep. Am J Physiol 252: E799-E802

YU W, NOMURA M, IKEDA M (2002) Interactivating feedback loops within the mammalian clock: BMAL1 is negatively autoregulated and upregulated by CRY1, CRY2, and PER2. Biochem Biophys Res Commun 290: 933-941

ZYLKA MJ, SHEARMAN LP, WEAVER DR, REPPERT SM (1998) Three period homologs in mammals: differential light responses in the suprachiasmatic circadian clock and oscillating transcripts outside of brain. Neuron 20: 1103-1110 